https://helda.helsinki.fi

\title{
The Lucianic Text of 1 Samuel : A Revised and Augmented Edition of the Old Greek
}

\section{Aejmelaeus, Anneli}

Vandenhoeck \& Ruprecht

2021

Aejmelaeus , A 2021, The Lucianic Text of 1 Samuel : A Revised and Augmented Edition of the Old Greek . in D Candido , J Alfaro \& K De Troyer (eds) , On Hexaplaric and Lucianic Readings and Recensions. De Septuaginta Investigationes, no. 014 , Vandenhoeck \& Ruprecht, Göttingen , pp. 39-54 . https://doi.org/10.13109/9783666522130.39

http://hdl.handle.net/10138/327993

https://doi.org/10.13109/9783666522130.39

unspecified

acceptedVersion

Downloaded from Helda, University of Helsinki institutional repository.

This is an electronic reprint of the original article.

This reprint may differ from the original in pagination and typographic detail.

Please cite the original version. 


\title{
The Lucianic Text of 1 Samuel
}

\section{A Revised and Augmented Edition of the Old Greek}

\author{
Anneli Aejmelaeus
}

\section{Introduction}

The textual history of the Greek text of Samuel-Kings - or the four Books of Kingdoms - has been the focus of scholarly discussion for more than one and a half centuries. After the identification of the so-called kaige recension by Dominique Barthélemy about fifty years ago one could have expected the topic little by little to lose its fascination and end up in a consensus of scholarly opinion. ${ }^{1}$ On the contrary, a new hot debate has been going on for some time on the nature of the Lucianic text, also known as the Antiochene text. ${ }^{2}$

As far as the manuscripts are concerned, the Lucianic textual tradition is easily definable in 1 Samuel: there are five manuscripts 19-82-93-108-127 for which the group siglum $L$ is used. Actually, the same manuscripts also represent the Lucianic text in the rest of the Books of Kingdoms. ${ }^{3}$ These manuscripts form a most unified family, clearly distinguishable from all other manuscripts groups, and the influence of this text-type is repeatedly shown in a number of further manuscripts (509 56-246 $55158245^{\mathrm{s}} 318$ ), which thus testify to its good reputation. Jerome mentions the Lucianic text among the three main branches of the Septuagint text, so that it must have existed - whether or not fully developed - towards the end of the $4^{\text {th }}$ century. ${ }^{4}$ Frequent quotation by Chrysostom and Theodoret confirm both the dating and the provenance.

What is remarkable is that this textual tradition does not witness to the kaige recension in those sections of Samuel-Kings where the majority of textual witnesses, including Codex Vaticanus and affiliated manuscripts (that is, the B text), has been under this influence. In those parts, the Lucianic

\footnotetext{
${ }^{1}$ Dominique Barthélemy, Les devanciers d'Aquila: Première publication intégrale du texte des fragments du Dodécaprophéton, VTSup 10 (Leiden: Brill, 1963). See also The Legacy of Barthélemy: 50 Years after Les Devanciers d'Aquila, ed. Anneli Aejmelaeus \& Tuukka Kauhanen, DSI 9 (Göttingen: Vandenhoeck \& Ruprecht, 2017).

${ }^{2}$ See for instance, Siegfried Kreuzer, "Towards the Old Greek: New Criteria for the Analysis of the Recensions of the Septuagint (Especially the Antiochene/Lucianic Text and Kaige Recension)," in XIII Congress of the International Organization of Septuagint and Cognate Studies, ed. Melvin K.H. Peters, SCS 55 (Atlanta: Society of Biblical Literature, 2008), 239-53. See also the critique of this position in T. Michael Law and Tuukka Kauhanen, "Methodological Remarks on the Textual History of Reigns: A Response to Siegfried Kreuzer," Bulletin of the International Organization for Septuagint and Cognate Studies 43 (2010), 73-87, as well as the reply to it, Siegfried Kreuzer, "A Reply to M. Law and T. Kauhanen, 'Methodological Remarks...", Bulletin of the International Organization for Septuagint and Cognate Studies 43 (2010), 89-95.

${ }^{3}$ There are in addition two fragmentary mss: Z (III Reg) and 700 (II and IV Reg).

${ }^{4}$ Jerome, Praef. in lib. Paralip.: "Alexandria and Egypt attribute the authorship of their Greek Old Testament to Hesychius. From Constantinople as far as to Antioch the rendering of Lucian the Martyr holds the field; while the Palestinian provinces in between these adopt those codices which, themselves the production of Origen, were promulgated by Eusebius and Pamphilus. And the whole world is in conflict with itself over this threefold variety of text." Translation according to Sidney Jellicoe, The Septuagint and Modern Study (Oxford: Clarendon Press, 1968), 134.
} 
text is obviously the best witness for the Old Greek, but the crucial question is: How close is it exactly to the original translation? And how strong is the recensional influence on it?

Barthélemy himself was hesitant in this matter; he first wrote that the Lucianic text is mainly equal to the Old Greek, but then admitted that it also contains recensional features. ${ }^{5}$ These seem to be the alternatives even in the present debate concerning the Lucianic text: is it genuine Old Greek or a recension or revision or edition ${ }^{6}$ This is the problem I wish to approach in this contribution of mine. My focus is, of course, the First Book of Samuel, which traditionally belonged to the non-kaige sections, but according to my studies has its share of kaige readings as well. Irrespective of the variations in the character of the B text, most scholars seem to think that the character of the Lucianic text is constantly the same in all the different sections of Samuel-Kings (or the four Books of Kingdoms). ${ }^{7}$ Accordingly, the characterization of the Lucianic text in 1 Samuel should be applicable to the other books as well.

The question now is: How does one proceed if the task is to characterize a textual tradition?

As far as we are dealing with copies of one and the same literary unit, all the various textual traditions have of course a great deal in common, and all of them also reveal more or less numerous agreements with the original from which they all derive. Just what percentage of the readings of a single manuscript or a textual family represent the original text, is a most intriguing question. However, this question can only be answered when the critical edition of the text is finished and the textual history is all cleared. In order to achieve this, one first needs to pay attention to the disagreements between the witnesses. Through the study of what is secondary one approaches the original text and defines the textual families. It is the secondary readings of a textual tradition that best of all characterize that tradition.

In this contribution, I would like to give examples of different kinds of readings that can be discovered in the Lucianic text of 1 Samuel: (1) secondary readings that show conscious editing of the text, (2) secondary readings that show connections with Hexaplaric materials, but also (3) a few tricky cases where $L$ represents the original text. I have tried to find key examples in which the relations between

\footnotetext{
${ }^{5}$ Having received critical comments on his Devanciers d'Aquila, Barthélemy revised his theory in "A Reexamination of the Textual Problems in 2 Sam 11:2-1 Kings 2:11 in the Light of Certain Criticism of 'Les Devanciers d'Aquila'," in 1972 Proceedings: Septuagint and Pseudepigrapha Seminars, ed. by R.A. Kraft, SCS 2 (Atlanta: Scholars Press, 1972) 16-89. See also Philippe Hugo, "The Books of Kingdoms Fifty Years after the Devanciers d'Aquila. Development of the Kaige Theory within Barthélemy's Works, and Some Implications for Present Research," in The Legacy of Barthélemy: 50 Years after Les Devanciers d'Aquila, ed. Anneli Aejmelaeus \& Tuukka Kauhanen, DSI 9 (Göttingen: Vandenhoeck \& Ruprecht, 2017) 23-40. Barthélemy seems to have differentiated between "recension" on the basis of the Hebrew text and "editions" with stylistic revisions of the Greek text only.

6 "Recension" (German "Rezension") is the term traditionally used in Septuagint scholarship when referring to a textform in which the text has been edited fairly consistently according to discernible principles. "Revision" refers to careful examination of the text (often in relation to the Hebrew text) with a view to making corrections and improvements. "Edition" is a more modern and neutral term that refers to one of the differing forms in which a literary work is published, either by the author or a subsequent editor.

${ }^{7}$ See especially Sebastian P. Brock, "Lucian redivivus: Some Reflections on Barthélemy's Les Devanciers d'Aquila," in SE 5 (1968) 176-81. For the recent discussion, see T. Michael Law and Tuukka Kauhanen, "Methodological Remarks on the Textual History of Reigns: A Response to Siegfried Kreuzer," Bulletin of the International Organization for Septuagint and Cognate Studies 43 (2010), 73-87.
} 
the different witnesses are as clear and unambiguous as possible. Such cases help to define the phenomena at work in the textual history of the book in question and to characterize the witnesses.

My focus is thus mainly - although not exclusively - on secondary readings of the Lucianic text. In order to be able to determine which reading is secondary, and which original, one needs to evaluate all the textual evidence there is. This is an important principle. ${ }^{8}$ All too often has the comparison been done between the Lucianic text and Codex Vaticanus (=B) only. The characterization of the witnesses needs to be based, case by case, on solid text-critical work and the solution of the problems often lies outside the two, the Lucianic text and Codex Vaticanus. ${ }^{9}$

\section{A Consciously Edited Text}

The Lucianic text is well known for its interest in Greek style and grammatical correctness. Its Atticizing features have been mentioned in all previous descriptions of the Lucianic text. ${ }^{10}$ I checked

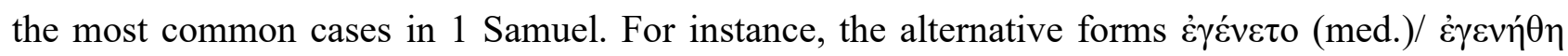

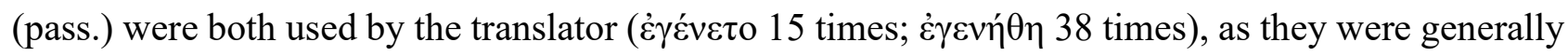
in Koine. The Lucianic text retains $\dot{\varepsilon} \gamma \varepsilon v \eta \dot{\theta} \eta$ just in two cases (1 Sam 30:1; 31:8); in all other cases the Lucianic text has $\dot{\varepsilon} \gamma \varepsilon \dot{v} \varepsilon \tau$, occasionally accompanied by a few other manuscripts (that may have made the same change independently), but 13 times alone. In those cases, where the translator had already used $\dot{\varepsilon} \gamma \varepsilon \dot{v} \varepsilon \tau$ o there is hardly any variation in the manuscripts.

Another example for variation between Koine and Atticizing forms is the aorist of $\lambda \dot{\varepsilon} \gamma \omega$. In the first person singular, the translator used $\varepsilon \tilde{i} \pi \alpha$ (with just one exception: $\varepsilon \tilde{i} \pi$ ov in 20:3) and in all the six cases of $\varepsilon \tilde{i} \pi \alpha$ the Lucianic text has the classical form $\varepsilon \tilde{i} \pi o v$. In the third person plural, there are 33 cases, all probably originally $\varepsilon \tilde{i} \pi \alpha v$ - although Rahlfs, following B, reads in eight cases $\varepsilon \dot{i} \pi o v .{ }^{11}$ The Lucianic text reads $\varepsilon i \pi \alpha v$ just once (23:3) and changes to the singular three times, to the historical present twice, having in all other cases عĩ

\footnotetext{
${ }^{8}$ For the method in practice, see for instance Anneli Aejmelaeus, “A Kingdom at Stake: Reconstructing the Old Greek Deconstructing the Textus Receptus," in Scripture in Transition: Essays on Septuagint, Hebrew Bible, and Dead Sea Scrolls in Honour of Raija Sollamo, ed. A. Voitila and J. Jokiranta, JSJS 126 (Leiden: Brill, 2008) 353-366; "Lectio difficilior and the Difficulties of the Critical Text: A Case study from the Septuagint of 1 Samuel 14:47," in XV Congress of the International Organization for Septuagint and Cognate Studies: Munich, 2013, ed. W. Kraus, M. van der Meer \& M. Meiser, SCS 64 (Atlanta, GA: Society of Biblical Literature, 2016) 61-70.

${ }^{9}$ The manuscripts available for the First Book of Samuel, with their tentative groupings, are the following (with those only partially preserved in parentheses): B A V (M) (842) (845) (846) (867); $O=247-376 ; L=19-82-93-108-127 ; C I=$ 98-(243)-379-731; $C I I=46-52-236-242-313-328-530 ; a=119-527-799 ; b=121-509 ; d=44-68-74-106-107-120-122-$ 125-134-(370)-610; $f=56-246 ; s=64-92-130-314-381-488-489-(762) ; 295571158244245318(342) 460554707$. As for the group sigla, $O$ stands for the Hexaplaric, $L$ for the Lucianic, $C$ for Catena manuscripts. See Offizielles Verzeichnis der Rahlfs-Sigeln. Stand: Dezember 2012, ed. Septuaginta-Unternehmen der Akademie der Wissenschaften zu Göttingen (https://rep.adw-goe.de/handle/11858/00-001S-0000-0022-A30C-8).

${ }^{10}$ Sebastian P. Brock, The Recensions of the Septuagint Version of 1 Samuel (Ph.D. dissertation, Oxford 1966), Quaderni di Henoch 9 (with a Foreword by Natalio Fernández Marcos; Torino: Silvio Zamorani, 1996), 224-56, has a most complete listing of all those forms in 1 Samuel in which there were differences between Koine and Atticistic Greek. See also Natalio Fernández Marcos, The Septuagint in Context: Introduction to the Greek Versions of the Bible (trans. Wilfred G.E. Watson; Boston/Leiden: Brill, 2001), 230-2.

${ }^{11}$ Similarly, Brock, The Recensions of the Septuagint Version of 1 Samuel, 229.
} 
Of those nouns that have a different article in Koine, "̌̉ $\lambda \varepsilon$ s $\varsigma$ 'mercy' (neuter in Koine) occurs in 1 Samuel four times $(15: 6,20: 8,14,15)$ : in all of these, the word appears as a masculine in the Lucianic text. Another one, ä $\lambda \omega \varsigma$ 'threshing floor' (masculine in Koine) occurs twice $(19: 22,23: 1)$ and has been changed in the Lucianic text to the feminine $\alpha \ddot{\lambda} \omega v$.

These few examples show that the changes from Koine forms to Atticistic forms was done quite regularly in the Lucianic text. Of course, such minor improvements could be done automatically by skillful scribes, and they did not change the text very much. However, the consistency with which such changes were made shows that those responsible for this textual tradition cared for the grammatical correctness of the text in small details in accordance with the scholarly fashion of their time $\left(4^{\text {th }}\right.$ century CE). ${ }^{12}$ It also shows that the editorial work on the text was not sporadic but rather was done with considerable thoroughness.

According to Sebastian Brock, certain stylistic changes were motivated by the desire to make the text more easily readable and comprehensible for those listening to its public reading. ${ }^{13}$ For instance, it is easy to find examples in which an implicit subject or object was made explicit, or some other clarification was added to the text. In these cases, the changes are often limited to the Lucianic text.

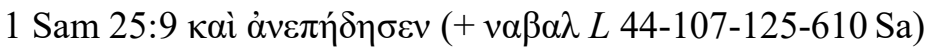

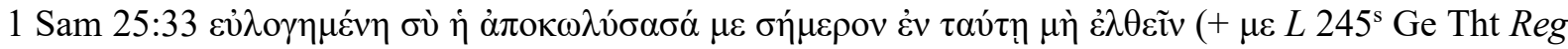

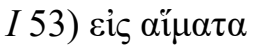

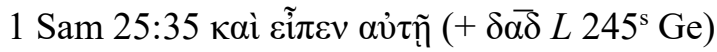

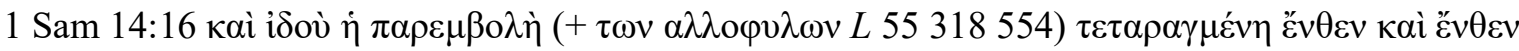

Already these minor details show that the Lucianic text is not a random product of manuscript copying but a consciously edited text. My next example, which is a fairly complicated case from 1 Sam 30, should make the point even more obvious. Already the first verses of the chapter show how freely the Lucianic editor could deal with the different manuscripts that obviously were at his disposal. ${ }^{14}$ In this example, it is a question of the comprehensibility of the whole story. ${ }^{15}$

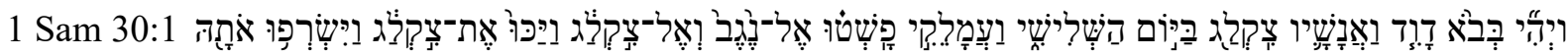

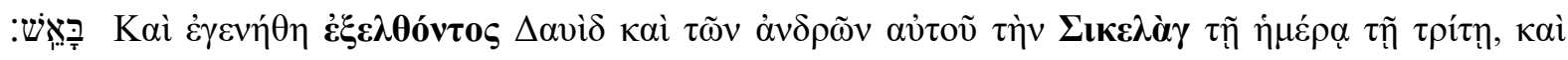

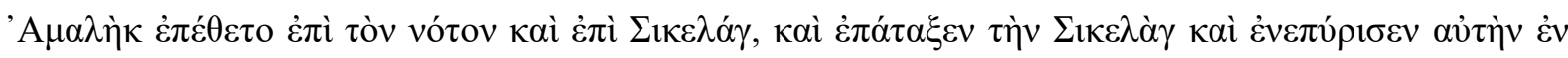
$\pi v \rho i$.

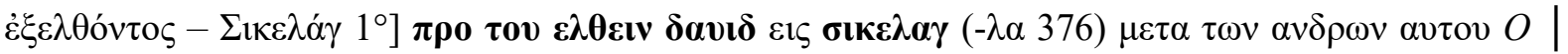

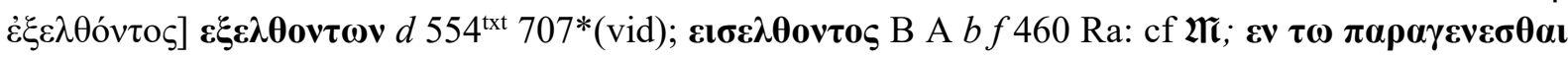
$L 554^{\mathrm{mg}}=\mathrm{MT}$

\footnotetext{
${ }^{12}$ Regardless of whether all the various features of the Lucianic text were created at one time, the beginning of this textual tradition must be sought in the $4^{\text {th }}$ century CE, since it is known already to Jerome. See note 4 above.

${ }^{13}$ Sebastian P. Brock, The Recensions of the Septuagint Version of 1 Samuel, 252.

${ }^{14}$ Whether one should speak of him, her, or them, when referring to the editor(s) of the Lucianic text-form is impossible to say.

${ }^{15}$ I have used this example before, but this time my focus is on the Lucianic text. For the text-critical decision, see my article "David's Return to Ziklag: A Problem of Textual History in 1 Sam 30:1," in XII Congress of the International Organization for Septuagint and Cognate Studies, Leiden 2004, ed. Melvin Peters, Septuagint and Cognate Studies 54 (Atlanta, GA: Society of Biblical Literature, 2006), 95-104.
} 


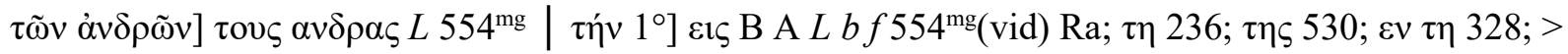

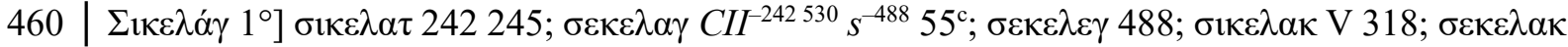

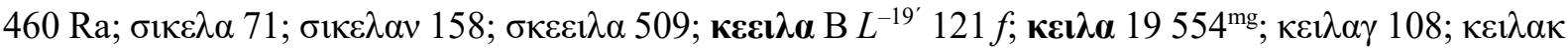
342

This is an extraordinary case in that the textual transmission is divided into four very different readings ( $\dot{\varepsilon} \xi \varepsilon \lambda \theta o ́ v \tau o \zeta, \varepsilon 1 \sigma \varepsilon \lambda \theta 0 v \tau \sigma \varsigma, \varepsilon v \tau \omega \pi \alpha \rho \alpha \gamma \varepsilon v \varepsilon \sigma \theta \alpha 1$, and $\pi \rho \circ \tau$ ov $\varepsilon \lambda \theta \varepsilon \imath v$, plus a fifth one that changes the singular to plural: $\varepsilon \xi \varepsilon \lambda \theta o v \tau \omega v)$. The text is not difficult as far as its words are concerned. What made it difficult to translate is that it contains a flashback.

The context of this example is the story about David marching with his Philistine landlord until Aphek to fight against the Israelites. However, he must return home, because other Philistine commanders do not trust him. In the beginning of chapter 30 , he is approaching his hometown Ziklag. In a flashback, the reader is informed about what had happened in David's absence: the Amalekites had raided his town. They had burnt Ziklag and taken the people captive. When David arrives in the town, he can see what has happened.

The Greek variant forms of the text show that both the translator and the later revisers had great difficulties in finding the correct expressions for the story. The crucial point is what is expressed in Hebrew as a circumstantial clause describing the situation as a result of what had happened in the meanwhile: "the Amalekites had raided Ziklag." In Greek, however, the aorist غं $\pi \dot{\varepsilon} \theta \varepsilon \tau$ can be taken

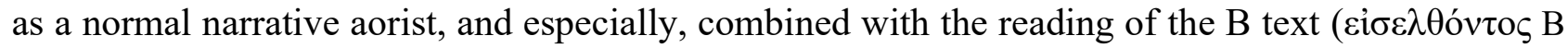
A $b f 460)$ it produces an impossible story: "When David came to Ziklag, the Amalekites raided the town", as if they would have done it in front of his eyes. This problematic formulation is found in Rahlfs's edition, but it is actually based on two manuscripts only, A and $460-\mathrm{B} b f$ transmitting another place name.

In fact, all the different textual traditions reveal different strategies of tackling with the problematic storyline. What happened to the text is easiest to explain by beginning with the majority reading

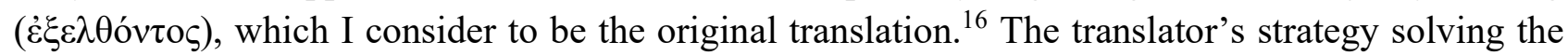
problem was to use a verbal form with the prefix $\dot{\varepsilon} \xi_{-}:{ }^{17}$ "as David had gone out of Ziklag..." This means a divergence from the Hebrew text, but the storyline is logical.

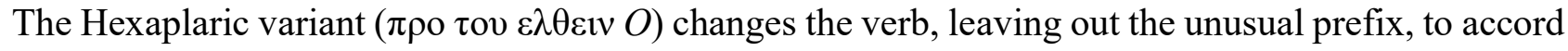
more closely with the Hebrew, and uses a construction with the infinitive, but surprisingly chooses the preposition $\pi \rho$ ó in order to coordinate the events: "before David came to Ziklag the Amalekites raided the town." This is of course again logical, but not what the Hebrew text says.

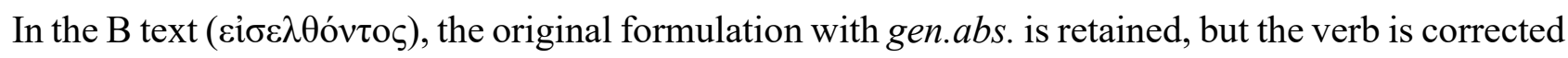

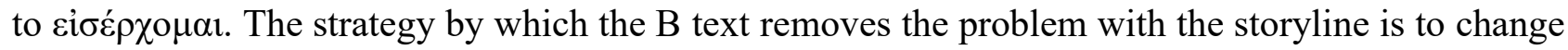
the name of the town: David is not yet arriving in his hometown Ziklag but stopping in Keilah. As

\footnotetext{
${ }^{16}$ I have argued for this solution in my article "David's Return to Ziklag: A Problem of Textual History in 1 Samuel 30:1."

${ }^{17}$ Translation of בוא by a verb with the preverb $\dot{\varepsilon} \xi$ - or $\dot{\alpha} \pi$ - is rare but not totally unique (cf. $\dot{\varepsilon} \xi \dot{\varepsilon} \rho \chi 0 \mu \alpha \imath 1$ Sam 4:3; $\dot{\alpha} \pi \varepsilon ́ \rho \chi 0 \mu \alpha \imath 25: 5)$.
} 
mentioned above, A and 460 are the only manuscripts that follow the Hebrew text in both details (the verb and the place name), but this cannot possibly be the original translation.

The Lucianic text ( $\varepsilon v \tau \omega \pi \alpha \rho \alpha \gamma \varepsilon v \varepsilon \sigma \theta \alpha 1 L 554^{\mathrm{mg}}$ ) uses another verb $\pi \alpha \rho \alpha \gamma i$ ío $\mu \alpha \mathrm{l}$ that frequently occurs as a rendering of בוא and a Hebraistic construction with $\dot{\varepsilon} v \tau \tilde{\omega}+$ the infinitive. The result is an exact rendering of the Hebrew verbal expression: "as David was arriving..." However, the Lucianic text also diverges from the Hebrew, using the same strategy as the B text: David is not yet arriving in Ziklag but he makes a stop at Keilah, while the Amalekites do their raid. This cannot be the original translation either. ${ }^{18}$

The reason for me to present this case is that it so clearly reveals some of the most characteristic features of the Lucianic text. It is important for the editor at work here that the storyline is logical. It is a question of the readability and comprehensibility of the text. The Lucianic editor takes great trouble in making it clear to the reader what is the position of David in the different phases of the story. He achieves this by the correction at the beginning and by additions, and in these additions he shows that he knows at least two other version of $\mathrm{v} .1$.

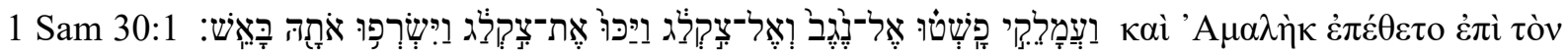

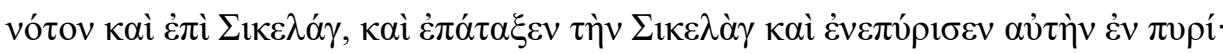

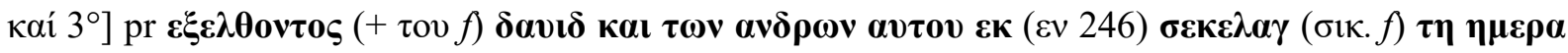
$\tau \eta \tau \rho \iota \tau \eta L f 554^{\mathrm{mg}}$

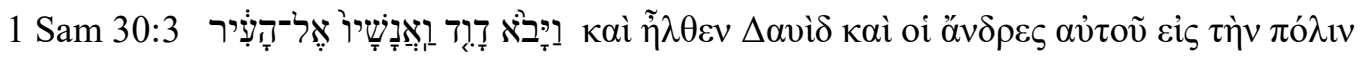

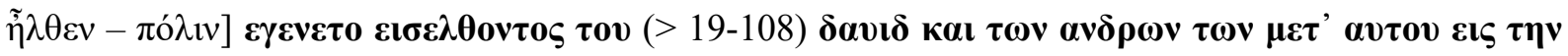

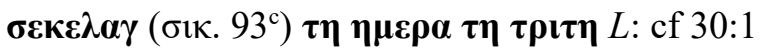

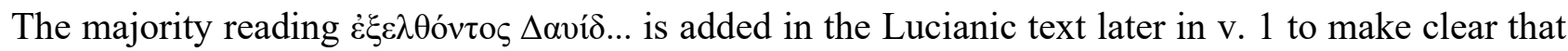

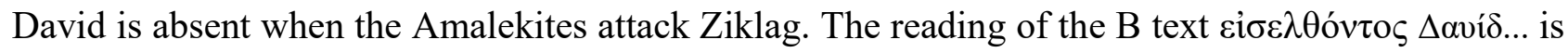
used in v. 3, which returns to the main storyline after the flashback. In v. 3, the gen.abs. halfway corresponds to the Hebrew wording, but the expression "on the third day" is also added from v. 1, just as it is repeated in v. 1. The Lucianic editor clearly shows his knowledge of the two other textual traditions. Thus, the corrupted mention of Keilah was probably picked up from the B text. Keilah was logical from the viewpoint of the storyline, but not necessarily from that of geography; it did not correspond to the Hebrew, and a different Vorlage is most improbable. The Lucianic editors, however, did not work with the Hebrew text but received even their Hebraistic corrections from other Greek translations. In this case the infinitive construction was perhaps adopted from one of the columns of the Hexapla.

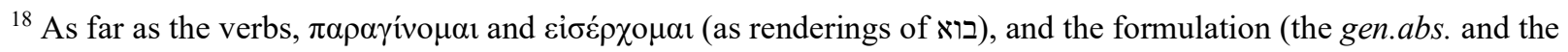
infinitive with a preposition) are concerned, both the B text and the Lucianic text correspond to the translation style of the original translator. However, the emergence of the various alternatives can only be explained from the majority reading, which is exceptional but as a contextual rendering also corresponds to this translator's characteristic way of proceeding. For a more detailed discussion, see "David's Return to Ziklag: A Problem of Textual History in 1 Samuel 30:1."
} 


\section{Adding Hexaplaric Materials}

Another well-known feature of the Lucianic text, for which examples can easily be found all over the text, is its employment of Hexaplaric materials. ${ }^{19}$ According to Brock, the Lucianic text is the best witness of Hexaplaric readings in 1 Samuel. One clear and extensive example is the complementation of the David and Goliath story, which is much shorter in the original Old Greek than in the MT. All the plusses of the MT have been complemented in the Lucianic text. ${ }^{20}$ In these complementations, the Lucianic text is clearly dependent on Hexaplaric materials but uses them in a distinctive way, often diverging from the other manuscripts that also complement the story according to the MT.

In the following examples it seems that the Lucianic editor is making improvements of his own to enhance the readability of the story. In 1 Sam 18:1 the story may have seemed too abrupt: when David quits talking to Saul, Jonathan is immediately attracted to him. The Lucianic editor adds more details to the story: "David came to Saul," and "Jonathan saw him." Who was talking to whom also seems to have been changed: in the MT, it is the young man David who talks to the king, but reading the Lucianic text one tends to see it the other way around: it is the king talking to the young hero - which also seems more appropriate. These changes are hardly based on any Hebrew or Greek Vorlage but must have been authored by the Lucianic editor.

\begin{tabular}{|c|c|c|}
\hline 1 Sam 18:1 MT & $\begin{array}{l}\text { Complementation } \\
\text { in mss A } O C I C I I d s\end{array}$ & $\begin{array}{l}\text { Complementation } \\
\text { in mss } L f 55158554^{\mathrm{mg}}\end{array}$ \\
\hline וַיְְּי & 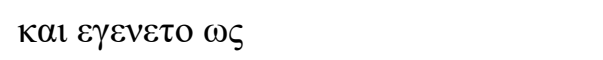 & $\kappa \alpha l \varepsilon \gamma \varepsilon v \varepsilon \tau \mathrm{\sigma} \omega \varsigma$ \\
\hline & & $\varepsilon 1 \sigma \eta \lambda \theta \varepsilon \Delta \alpha v 1 \delta \pi \rho \mathrm{s} \Sigma \Sigma \alpha \mathrm{ov} \lambda \kappa \alpha \mathrm{l}$ \\
\hline 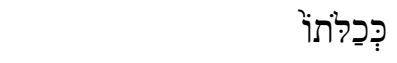 & $\sigma v v \varepsilon \tau \varepsilon \lambda \varepsilon \sigma \sigma \varepsilon$ & $\sigma 0 v \varepsilon \tau \varepsilon \lambda \varepsilon \sigma \varepsilon$ \\
\hline 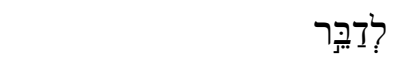 & $\lambda \alpha \lambda \omega \nu \quad(\delta \bar{\delta} O)$ & $\lambda \alpha \lambda \omega v$ \\
\hline אֶל־שָׁאוּל & $\pi \rho \circ \varsigma \Sigma \alpha o v \lambda \quad(\varepsilon v \omega \pi$ lov $\Sigma \alpha \circ \nu \lambda O)$ & $\alpha v \tau \omega$ \\
\hline & & $\varepsilon 1 \delta \varepsilon v \alpha v \tau \mathrm{I} \mathrm{I} \omega v \alpha \theta \alpha v$ \\
\hline 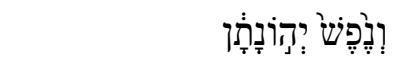 & $\kappa \alpha \iota \eta \psi v \chi \eta \mathrm{I} \omega v \alpha \theta \alpha v(+\tau$ ov viov $\Sigma . O)$ & \\
\hline נִקְשְׁרָה & $\sigma 0 v \varepsilon \delta \varepsilon \theta \eta$ & $\kappa \alpha \iota ~ \sigma v v \varepsilon \delta \varepsilon \theta \eta$ \\
\hline & & $\eta \psi v \chi \eta \alpha v \tau o v \quad(>f)$ \\
\hline 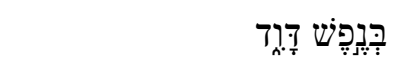 & $\tau \eta \psi v \chi \eta \Delta \alpha v 1 \delta$ & $\tau \eta \psi v \chi \eta \Delta \alpha v 1 \delta$ \\
\hline 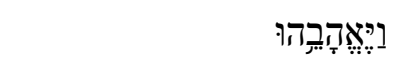 & $\kappa \alpha \iota ~ \eta \gamma \alpha \pi \eta \sigma \varepsilon v \alpha \nu \tau o v$ & $\kappa \alpha \iota ~ \eta \gamma \alpha \pi \eta \sigma \varepsilon v \alpha \nu \tau o v$ \\
\hline 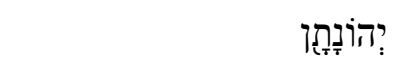 & $\mathrm{I} \omega v \alpha \theta \alpha \nu$ & $\mathrm{I} \omega v \alpha \theta \alpha v$ \\
\hline 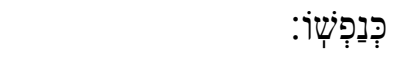 & $\kappa \alpha \tau \alpha \tau \eta \nu \psi v \chi \eta \nu \alpha v \tau o v$ & $\kappa \alpha \tau \alpha \tau \eta \nu \psi v \chi \eta \nu \alpha v \tau \circ v$ \\
\hline
\end{tabular}

This is also true in the second example 1 Sam 18:6, in which the editor has simply improved the style and grammatical correctness.

\footnotetext{
${ }^{19}$ See Brock, The Recensions of the Septuagint Version of 1 Samuel, 150-8

${ }^{20}$ The two longer passages added in the MT are: 1 Sam 17:12-31 and 17:55 - 18:5; whole sentences have been added in vv. 17:37, 38, 41, 42, 48, 50, 51; 18:6, 8, 10-11, 12, 17-19, 21, 26, 27, 28, 29-30, and in addition to these, single words or phrases have been added all over the two chapters. Not all Greek manuscripts that have complementations have succeeded in complementing all the words and sentences that are lacking in the Septuagint.
} 


\begin{tabular}{|c|c|c|}
\hline $1 \mathrm{Sam}$ 18:6 MT & $\begin{array}{l}\text { Complementation } \\
\text { in mss A } O C I C I I d s\end{array}$ & $\begin{array}{l}\text { Complementation } \\
\text { in mss } L f 55158\end{array}$ \\
\hline נוּיְניהי & 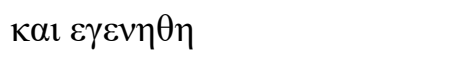 & 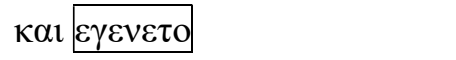 \\
\hline דְִּבוֹאָּם & 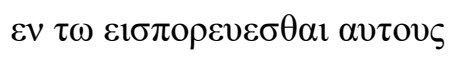 & $\varepsilon v \tau \omega \varepsilon \iota 1 \sigma \pi \mathrm{o} \rho \varepsilon v \varepsilon \sigma \theta \alpha \iota \alpha v \tau \mathrm{ov} \varsigma$ \\
\hline 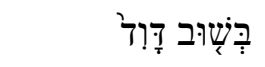 & $\varepsilon v \tau \omega \varepsilon \pi \imath \tau \tau \rho \varepsilon \varphi \varepsilon \downarrow v \Delta \alpha v \imath \delta$ & $0 \tau \varepsilon \varepsilon \pi \varepsilon \sigma \tau \rho \varepsilon \psi \varepsilon \Delta \alpha v 1 \delta$ \\
\hline מֶהכבְּוֹת & $\alpha \pi \mathrm{o} \tau \mathrm{ov} \pi \alpha \tau \alpha \xi \alpha \iota$ & $\pi \alpha \tau \alpha \xi \alpha \varsigma$ \\
\hline 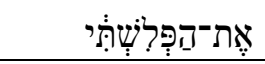 & $\tau \mathrm{T} v \alpha \lambda \lambda \mathrm{O} \varphi \nu \lambda \mathrm{ov}$ & $\tau \mathrm{T} \nu \alpha \lambda \lambda \mathrm{\rho} \varphi v \lambda \mathrm{ov}$ \\
\hline
\end{tabular}

In many cases, the Hexaplaric additions seem to be in contradiction with the stylistic ideals of the Lucianic editors, because the formulation is so strongly Hebraistic, but here we can see that the improvement of the style of these additions was also possible. However, it is possible (and probable) that Hexaplaric plusses were added to the Lucianic text over a longer period of time.

It is obvious that the Lucianic editors had more Hexaplaric material at their disposal than just Origen's fifth column or the tradition of the asterisked additions, and they seem to have been particularly interested in the translation of Symmachus. In a few lucky cases we do have evidence in marginal notes of the Hexaplaric origin of a reading that is found in the Lucianic text.

An example of a reading from Symmachus is found at 1 Samuel 16:14:

\begin{tabular}{|c|c|c|}
\hline $\mathrm{MT}$ & LXX & $L$ \\
\hline 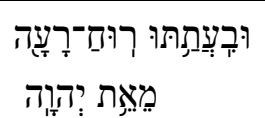 & 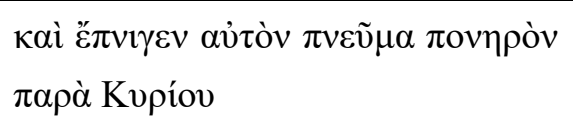 & 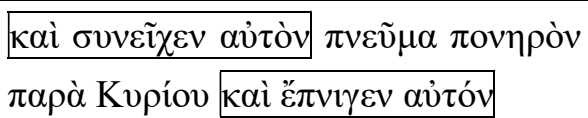 \\
\hline
\end{tabular}

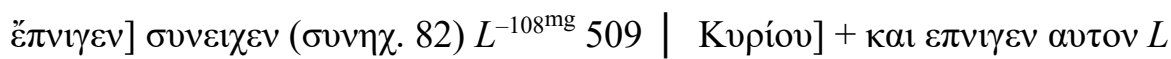

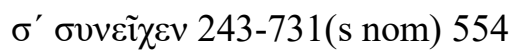

According to the Hebrew "the evil spirit tormented" Saul. The Old Greek translates it with $\pi v i$ $\gamma \omega$ "strangle," whereas $L$ says: "the evil spirit took hold of him." The attribution to Symmachus is found in marginal notes of two manuscripts. The Lucianic editor found this expression appropriate to be used in the first place, but did not want to leave out the Old Greek rendering, either, and thus created a kind of doublet. Interestingly, none of the verbs corresponds to the Hebrew.

Vocabulary of Symmachus is also found in the following two cases, in which the variant represents more idiomatic Greek:

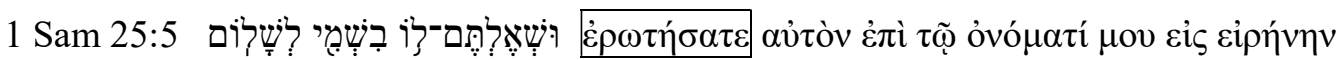

$\dot{\varepsilon} \rho \omega \tau \eta ́ \sigma \alpha \tau \varepsilon] \alpha \sigma \pi \alpha \sigma \alpha \sigma \theta \varepsilon L 554^{\mathrm{mg}} \mid \varepsilon v \varepsilon \iota \rho \eta \nu \eta L$

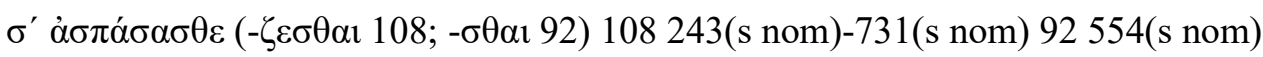

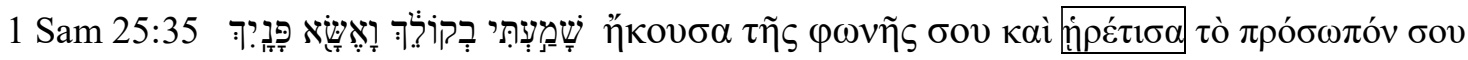

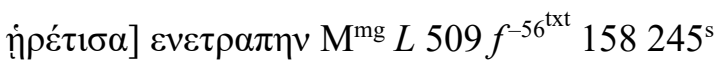

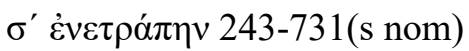


At 16:20 $L$ combines renderings of two alternative Hebrew readings and complements the sentence independently. This adds to the story a further detail informing the reader of the way of transporting the food supplies.

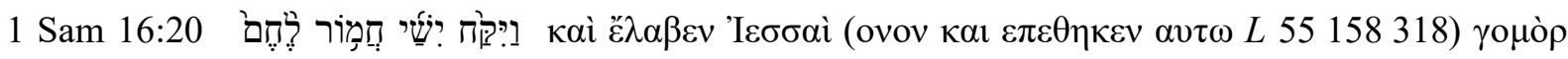

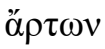

The numerous transliterations in 1 Samuel were of course a problem for someone who cared for the comprehensibility of the text. In many cases, the Lucianic text provides a translation which is likely to have originated with one of the Three.

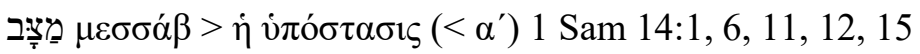

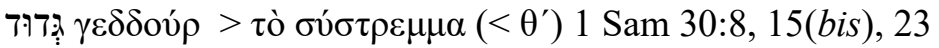

An incomprehensible transliteration could also be omitted:

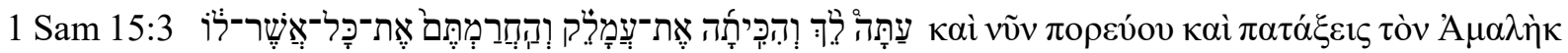

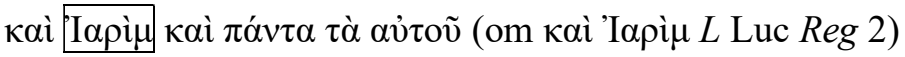

In many of these examples we can observe that the Lucianic editor or editors could be quite creative in combining different readings and adding their own clarifications. It seems to me that the main principle for them was to enhance the readability and comprehensibility of the text and if possible to give more effect to the story.

How is it possible that the Lucianic text could be so freely expanded? One explanation is that the editors were not comparing the Greek text directly with the Hebrew, and so, they were not aware that the different expressions that were combined actually derived from one and the same Hebrew text or variant forms of the same. The traditional Old Greek text used by the Church seems to have been highly valued and authoritative as such; however, it could be improved in its grammatical formulation and if there were any incomprehensible details they could be clarified.

Approximations to the Hebrew text came to the attention of the Lucianic editors either through Origen's Hexapla, or manuscripts copying excerpts from its various columns, or possibly also directly from the versions of Theodotion or Symmachus or Aquila - the Three that were known to adhere closely to the Hebrew text. ${ }^{21}$ Some of the readings that were not represented in the traditional text were perhaps first placed in the margin of the edition from where they would eventually have slipped into the main text, as suggested by Anna Kharanauli. ${ }^{22}$ This might have happened over a longer period of time and concerned especially the asterisked additions. Otherwise, I think that the changes were consciously planned and carried out rather than resulting from random slips. As an editorial principle, approximation to the Hebrew text must, however, be considered as secondary and subordinate to the

\footnotetext{
${ }^{21}$ Since the Three are known through fragmentary readings only, it is impossible to know precisely to what extent they consisted of revision of the Septuagint or new, independent translation. After Barthélemy's Les devanciers d'Aquila, most scholars tend to see a continuum from the kaige revision to Theodotion, and further to Aquila, regarding Theodotion still as a revision fairly close to the traditional Septuagint but Aquila as a new translation. Symmachus is generally seen as an independent translation with an inclination towards more elegant Greek. What is common to all Three is their strict adherence to the contemporary Hebrew text. See for instance, Fernández Marcos, The Septuagint in Context: Introduction to the Greek Versions of the Bible, 109-154.

${ }^{22}$ See Anna Kharanauli, "Origen and Lucian in the Light of Ancient Editorial Techniques," in From Scribal Error to Rewriting: How Ancient Texts Could and Could Not be Changed, ed. Anneli Aejmelaeus, Drew Longacre and Natia Mirotadze, DSI 12 (Vandenhoeck \& Ruprecht: Göttingen, 2020), 15-52.
} 
principle of improving style and readability. In a sense, one could say that Origen's work was misused in the Lucianic textual tradition.

My thesis is that the Lucianic text is not a random product of manuscript copying but a consciously edited text. In several respects, the scribes and scholars of Antioch must have worked like editors of a text normally do. Scholars often remark that the basic text of the Antiochene tradition was a good old manuscript, but they seldom seem to think that these early editors may have consciously chosen their basic text from a number of manuscripts available to them. ${ }^{23}$ Even if the Lucianic editors did not follow our text-critical principles, they certainly understood that an old manuscript that was the result of relatively few times of copying would contain fewer errors.

\section{Preserving Original Readings}

The most intriguing aspect of the Lucianic textual tradition is of course its preservation of original readings. How to recognize such readings among all those editorial features that have been presented so far is a major question in the textual criticism of 1 Samuel as well as the rest of Samuel-Kings.

A good example of what is going on in the Lucianic text is 1 Sam 15:11, where God is speaking to Samuel and expressing his rejection of Saul. In this case my critical text will differ from Rahlfs's text at three points: ${ }^{24}$

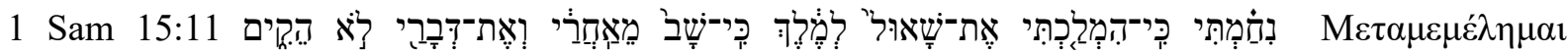

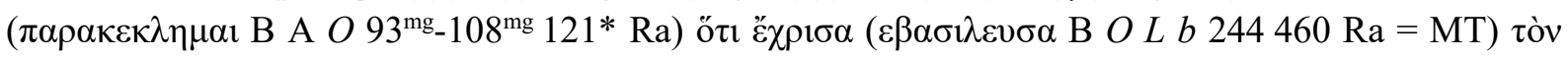

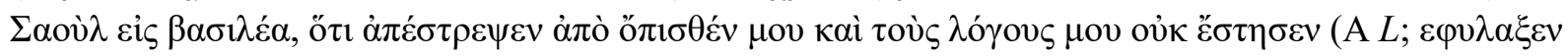
O CII $121 s ; \varepsilon \tau \eta \rho \eta \sigma \varepsilon v$ rel Ra; statuit $\left.\mathrm{La}^{116}\right)$.

("I have regretted that I anointed Saul to king, because he has turned away from following me, and my words he has not established.")

Rahlfs, of course, follows Vaticanus in all three readings. The Lucianic text is a witness of the Old Greek, but only in two of the three cases. (1) In the first case, $L$ witnesses the OG $\mu \varepsilon \tau \alpha \mu \varepsilon \mu \varepsilon \dot{\varepsilon} \eta \mu \alpha \mathrm{l}$ with the majority of manuscripts against the kaige-type (pre-hexaplaric, Jewish) correction according to the Hebrew text, which however appears as a marginal reading in two manuscripts of the $L$ group. (2) In the second case ( $\check{\chi} \chi \rho 1 \sigma \alpha)$, in which the Vorlage had משח 'to anoint,' $L$ has adopted the early correction according to the MT $\dot{\varepsilon} \beta \alpha \sigma i ́ \lambda \varepsilon v \sigma \alpha$ - maybe for the sake of clarity. I would not say that $L$ is affected by the kaige recension or contaminated by it, but prefer to say that the editor deliberately chose the reading, because it made sense to him, whereas in the previous case it did not. (3) In the third case, the original OG $\varepsilon \sigma \tau \eta \sigma \varepsilon v$ is preserved just in A and $L$ in a reading that clearly represents

\footnotetext{
${ }^{23}$ See Jellicoe, The Septuagint and Modern Study, 157-171.

${ }^{24}$ For a discussion of this case, see my "A Kingdom at Stake: Reconstructing the Old Greek - Deconstructing the Textus Receptus," in Scripture in Transition: Essays on Septuagint, Hebrew Bible, and Dead Sea Scrolls in Honour of Raija Sollamo, ed. Anssi Voitila and Jutta Jokiranta, JSJSup 126 (Leiden: Brill, 2008), 353-66. See also my article "Does God Regret? A Theological Problem that Concerned the Kaige Revisers," in Legacy of Barthélemy: 50 Years after Les Devanciers d'Aquila, ed. Anneli Aejmelaeus and Tuukka Kauhanen, DSI 9 (Göttingen: Vandenhoeck \& Ruprecht, 2017), 41-53.
} 


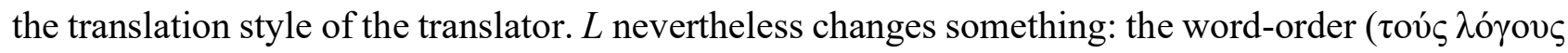

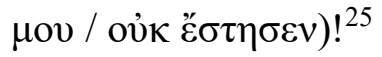

In many cases, the Lucianic text witnesses the original text along with a number of other manuscripts (often the majority of manuscripts against an early correction):

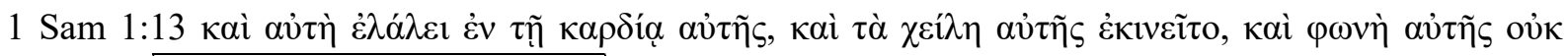

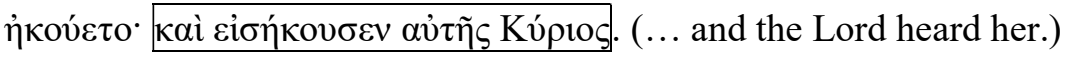

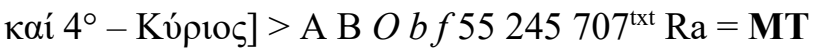

The Old Greek contains a quotation from the Rachel story (Gen 30:22), which must have been in Hebrew in the Vorlage. It is not present in the MT and was thus left out through an early approximation. $L$ witnesses the Old Greek together with the majority of manuscripts.

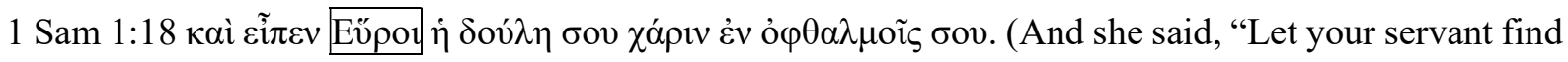
favour in your eyes.")

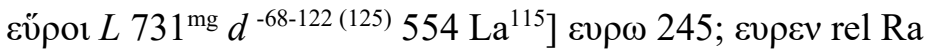

The optative is stylistically the better form here, but it also corresponds to the Hebrew imperfect, which is normally not rendered by the aorist. The translator of 1 Samuel is capable of using the optative. The majority reading can easily be explained as a corruption in uncial letters. In addition to $L$, the Old Greek is witnessed here just by a few scattered manuscripts - except for Vetus Latina $\left(\mathrm{La}^{115}\right)$, which is a very important, independent witness.

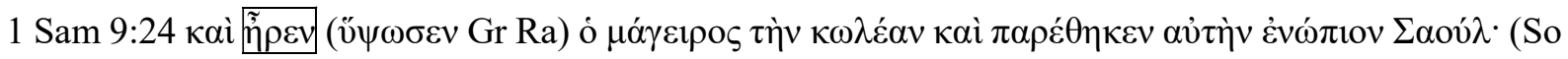
the cook took up the leg and set it before Saul.)

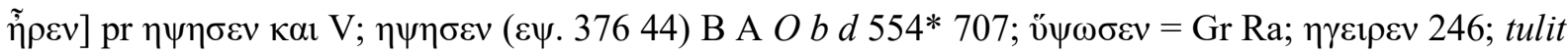

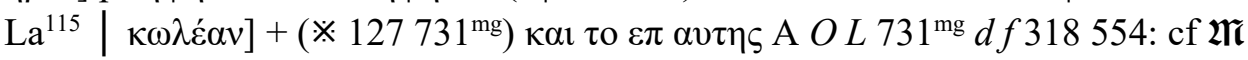

Rahlfs accepted $̋ \psi \omega \sigma \varepsilon v$ which is Grabe's clever conjecture of $\eta \psi \eta \sigma \varepsilon v$. However, these two scholars did not realize that the corrupted reading was in fact a kaige-type correction aiming to represent more

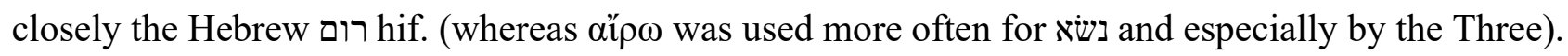
The Lucianic text, with a number of independent witnesses, stands for the Old Greek in the verb, but reveals a few words later a Hexaplaric addition.

\section{Conclusions}

In a short contribution like this, it is not possible to show exhaustive examples of the textual phenomena touched upon. Looking for examples to be shown and concentrating for a change on the

\footnotetext{
${ }^{25}$ The criterion for the original text is in each of the three cases different: in (1) there is a theologically motivated, Kaige-type change vs. normal translation style, in (2) the change in the Hebrew text is revealed by the double expression "to king"; "anoint to king" was the Vorlage and the original Hebrew text as well as the Old Greek, even though Codex Vaticanus and $L$ agree in reading $\dot{\varepsilon} \beta \alpha \sigma i ́ \lambda \varepsilon v \sigma \alpha$; in (3) the decisive factors are translation technique and the probability of corruption. For a more detailed disccussion, see my article "A Kingdom at Stake: Reconstructing the Old Greek - Deconstructing the Textus Receptus."
} 
Lucianic text, I was myself surprised that there is so much independent activity in the Lucianic text. It is a truly eclectic text, as many other textual traditions are. There are readings that are not supported by other witnesses and readings in which the Lucianic text is followed by certain typical companions. And then there are readings in which the Lucianic text agrees with a number of independent witnesses. In the last-mentioned cases, if they are in harmony with what we know about the translation of 1 Samuel and do not fill the characteristics of Hexaplaric readings, I have no difficulty in accepting such readings as the original Old Greek. I am however hesitant in cases where $L$ is alone or followed just by its typical companions. In this respect the situation in the kaige sections is probably different.

It is often said that $L$ was untouched by the kaige recension. It seems to me, however, that the Lucianic editors were not totally ignorant of kaige readings. They seem to have known readings of the B text in cases where the B text has a kaige-type approximation. In some cases, this may have been due to a coincidence with the Hexaplaric material that was used frequently to improve or complement the text with interesting details. The Lucianic editors did not work with the Hebrew text, and for this reason, the Hebrew text did not function for them as a control of what belonged to the text and what did not. Using Aquila, Symmachus and Theodotion was felt to be safe because they were known to be in harmony with the Hebrew. Readings that enhanced the readability of the story could be chosen and added to the text. As a result, there are also many doublets.

It is obvious that the Lucianic editors had several manuscripts at their disposal, among them good old manuscripts and ones with kaige-type readings. But how do we know which readings of the Lucianic text represent the good old basic text? Sometimes these readings are buried under Atticizing corrections or changes of word-order or partial additions of Hexaplaric readings. In many cases, they can be recognized and established as part of the original text, but the only way to achieve this is a full text-critical and translation-technical analysis. In this respect, the Lucianic text is no special case. There are no shortcuts, no a priori probabilities of finding original readings in the Lucianic textual tradition.

\section{Bibliography}

Aejmelaeus, Anneli, "David's Return to Ziklag: A Problem of Textual History in 1 Sam 30:1," in XII Congress of the International Organization for Septuagint and Cognate Studies, Leiden 2004, ed. Melvin Peters, Septuagint and Cognate Studies 54 (Atlanta, GA: Society of Biblical Literature, 2006), 95-104.

Aejmelaeus, Anneli, "A Kingdom at Stake: Reconstructing the Old Greek - Deconstructing the Textus Receptus," in Scripture in Transition: Essays on Septuagint, Hebrew Bible, and Dead Sea Scrolls in Honour of Raija Sollamo, ed. A. Voitila and J. Jokiranta, JSJSup 126 (Leiden: Brill, 2008), 353-366.

Aejmelaeus, Anneli, "Lectio difficilior and the Difficulties of the Critical Text: A Case study from the Septuagint of 1 Samuel 14:47," in XV Congress of the International Organization for Septuagint and Cognate Studies: Munich, 2013, ed. W. Kraus, M. van der Meer \& M. Meiser, SCS 64 (Atlanta, GA: Society of Biblical Literature, 2016), 61-70.

Aejmelaeus, Anneli, "Does God Regret? A Theological Problem that Concerned the Kaige Revisers," in Legacy of Barthélemy: 50 Years after Les Devanciers d'Aquila, ed. Anneli Aejmelaeus and Tuukka Kauhanen, DSI 9 (Göttingen: Vandenhoeck \& Ruprecht, 2017), 41-53. 
Aejmelaeus, Anneli and Tuukka Kauhanen (eds.), The Legacy of Barthélemy: 50 Years after Les Devanciers d'Aquila, DSI 9 (Göttingen: Vandenhoeck \& Ruprecht, 2017).

Barthélemy, Dominique, Les devanciers d'Aquila: Première publication intégrale du texte des fragments du Dodécaprophéton trouvés dans le désert de Juda: précédée d'une étude sur les traductions et recensions grecques de la Bible réalisées au premier siècle de notre ère sous l'influence du rabbinat Palestinien, VTSup 10 (Leiden: Brill, 1963).

Barthélemy, Dominique, "A Reexamination of the Textual Problems in 2 Sam 11:2-1 Kings 2:11 in the Light of Certain Criticism of 'Les Devanciers d'Aquila',' in 1972 Proceedings: Septuagint and Pseudepigrapha Seminars, ed. by R.A. Kraft, SCS 2 (Atlanta: Scholars Press, 1972) 16-89.

Brock, Sebastian P., The Recensions of the Septuagint Version of 1 Samuel (Ph.D. dissertation, Oxford 1966), Quaderni di Henoch 9 (with a Foreword by Natalio Fernández Marcos; Torino: Silvio Zamorani, 1996).

Brock, Sebastian P., "Lucian redivivus: Some Reflections on Barthélemy's Les Devanciers d'Aquila," SE 5 (1968) 176-81.

Fernández Marcos, Natalio, The Septuagint in Context: Introduction to the Greek Versions of the Bible (trans. Wilfred G.E. Watson; Boston/Leiden: Brill, 2001),

Philippe Hugo, "The Books of Kingdoms Fifty Years after the Devanciers d'Aquila. Development of the Kaige Theory within Barthélemy's Works, and Some Implications for Present Research," in The Legacy of Barthélemy: 50 Years after Les Devanciers d'Aquila, ed. Anneli Aejmelaeus \& Tuukka Kauhanen, DSI 9 (Göttingen: Vandenhoeck \& Ruprecht, 2017) 23-40.

Jellicoe, Sidney, The Septuagint and Modern Study (Oxford: Clarendon Press, 1968).

Kharanauli, Anna, "Origen and Lucian in the Light of Ancient Editorial Techniques," in From Scribal Error to Rewriting: How Ancient Texts Could and Could Not be Changed, ed. Anneli Aejmelaeus, Drew Longacre and Natia Mirotadze, DSI 12 (Göttingen: Vandenhoeck \& Ruprecht, 2020), 15-52.

Kreuzer, Siegfried, "Towards the Old Greek: New Criteria for the Analysis of the Recensions of the Septuagint (Especially the Antiochene/Lucianic Text and Kaige Recension)," in XIII Congress of the International Organization of Septuagint and Cognate Studies, ed. Melvin K.H. Peters, SCS 55 (Atlanta: Society of Biblical Literature, 2008), 239-53.

Kreuzer, Siegfried, "A Reply to M. Law and T. Kauhanen, 'Methodological Remarks...", Bulletin of the International Organization for Septuagint and Cognate Studies 43 (2010), 89-95.

Law, T. Michael and Tuukka Kauhanen, "Methodological Remarks on the Textual History of Reigns: A Response to Siegfried Kreuzer," Bulletin of the International Organization for Septuagint and Cognate Studies 43 (2010), 73-87. 